\title{
Presence of Microplastics in Windowpane Oyster Placuna placenta and the waters from the Tambak Lorok Coastal Area in Central Java, Indonesia
}

\author{
Eduard M. Tielman ${ }^{1 *}$, Lisa F. Indriana ${ }^{2,3}$, Ita Widowati4,5, Ambariyanto Ambariyanto ${ }^{4,5}$ \\ ${ }^{1}$ Master student of Marine Science, Faculty of Fisheries and Marine Science, Universitas Diponegoro \\ Jl. Prof. H. Soedharto, SH, Tembalang, Semarang, 50275 Indonesia \\ ${ }^{2}$ Marine Bio Industry, National Research and Innovation Agency (BRIN) Indonesia \\ Jl. Raya Senggigi, Malaka, Pemenang, Lombok, 83352 Indonesia \\ ${ }^{3}$ Alfred-Wegener-Institute, Helmholtz Center for Polar and Marine Research \\ Am Handelshafen 12, 27570 Bremerhaven, Germany \\ ${ }_{4}^{4}$ Department of Marine Science, Faculty of Fisheries and Marine Science, Universitas Diponegoro \\ ${ }^{5}$ Center for Coastal Disaster Mitigation and Rehabilitation, Universitas Diponegoro \\ Jl. Prof. H. Soedharto, SH, Tembalang, Semarang, 50275 Indonesia \\ Email: tielmannino@gmail.com
}

\begin{abstract}
Indonesia is the second-largest contributor of plastic debris in the world. The abundance of plastic debris and the bioavailability of its fragmented form known as Microplastics (MPs; < $5 \mathrm{~mm}$ of size) can be dangerous for marine environments. This study investigates the presence of MPs in the sea water and marine organisms (Placuna placenta) at Tambak Lorok Waters located at the coast of Semarang city, Central Java, Indonesia. All of the microplastics collected from both samples were identified by their shape, color, size (using Olympus Stereo Microscope), and polymer type (using Fourier Transform Infra-Red Spectroscopy/FTIR). The study found that the Microplastic concentration in the water samples had an average of 12.6 particles. $L^{-1}$, where the color and size distribution were predominantly blue colored fragments sized less than $50 \mu \mathrm{m}$. Examination of the study area showed that microplastics concentration in P. placenta was 1 item and 0.033 items. $\mathrm{g}^{-1}$ for each of the organism. Whereas for physical aspects of microplastics found in the oysters showed the blue colored fibers with range size 300-1000 $\mu \mathrm{m}$ were mostly present. Majority of the polymer types of microplastics found in this study were lowdensity polyethylene, nylon, polystyrene, and polypropylene. Data from this study shows that microplastics were present in the Tambak Lorok coastal waters. However, there was no significant statistical correlation between the concentration of microplastics in the seawater and the P. placenta, the presence of microplastics in the seawater were found to be ingested by the P. placenta.
\end{abstract}

Keywords: FT-IR, Microplastics, P. placenta, Tambak Lorok

\section{Introduction}

Marine pollution, namely the presence of Microplastics, causes loss of biodiversity and extinction of marine organisms (Ambariyanto, 2017). In the marine environment, plastic waste pollution is a global problem that is attributed to the marine or land actvities of humans where used plastics are discarded into the marine coastal area (Nerland et al., 2014). Plastics Europe (2015) reported that the world plastic production increased from 1.5 million tonnes to 299 million tonnes from in 1950 to 2013. The report also indicated that there is a significant increase of $4 \%$ per year from 2012, in which more than 10 million tons of terrestrial plastic waste are found in the oceans each year (Löhr et al., 2017). Khoironi et al. (2020) study indicated that approxiately 2 tons of plastic waste can be found flowing into this coastal area every day.
Indonesia has about 3.22 million tons of unmanaged plastic in which approximately 0.48 1.29 million tons of plastic waste from this country are potentially entering the sea (Jambeck et al., 2015). The large population in Indonesia and the lack of adequate waste management contributes to this large amount of plastic waste (Syakti et al., 2017). Some of this plastic waste is in the form of macro and microplastics $(<5 \mathrm{~mm})$, which deposits onto the seabed and polluting the marine environment (Browne, 2015).

There are two types of microplastics based on their source: primary microplastics, which can be attributed to manufactured plastics in microscopic sizes including scrubbers and pellets (Isobe, 2016) and secondary microplastics, which can be derived from the degradation of macroplastic such as fragments, fibers, or films (Lusher et al., 2017). The presence of microplastics its impact on ingestion 
(Cole et al. 2013), adherence (Kolandhasamy et al., 2018), and trophic transfer (Farrell and Nelson, 2013) in marine organisms has been of particular concern of late.

Steer et al. (2017) said that different life stages of certain species can ingest plastics from their habitat or environment. Many species of shellfish have been widely used in microplastics biomonitoring in marine environments due to several advantages such as broad geographical distribution, easy accessibility, and high tolerance to a considerable range of salinity (Kusnoputranto et al., 2014; Li et al., 2018: Tubagus et al., 2020).

The World Bank Group (2018) reported that the city of Semarang in the island of Central Java, Indonesia, generated 1387.9 tons of municipal solid waste (MSW) daily with a total population of $1,595,267$. Among this solid waste amount, 300.5 tons were unmanaged with $35.3 \%$ of plastics waste composition found in the non-tidal zone of the city. One plausable explanation for this finding is the existance of rivers from within the city that floats plastic waste out to the estuary and coastal areas. One particular area identified for this study is the Tambak Lorok coastal area, which is currently used as the main hub for selling and supplying marine products from and to the city of Semarang.

This study investigated the abundance of microplastics in the Tambak Lorok coastal area and in a marine organism, windowpane oyster Placuna placenta, taken also from the same coastal reagion. The oyster was chosen for this study due to its popularity as a food source for coastal community daily diet.

\section{Materials and Methods}

This study was conducted at Tambak Lorok Coastal Area, Semarang City, Central Java, Indonesia, which is known as the largest marine product market in the city (Figure 1.). All samples used in this study (water and $P$. placenta) were collected in October 2019. Microplastics were collected from seawater with plankton nets (Hidalgo-Ruz et al., 2012; Barrows et al., 2017). The net has a $25 \mathrm{~cm}$ diameter circular opening, attached with a $85 \mathrm{~cm}$ long-net that has a $25 \mu \mathrm{m}$ mesh opening. The net was attached to the side of the motorboat travelling at a constant speed of 3 knots $(1.6 \mathrm{~m} / \mathrm{s})$ for a duration of $1 \mathrm{~min}$ for approximately $100 \mathrm{~m}$. Volume of water that flowed and filtered through the net was approximately \pm $5 \mathrm{~m}^{3}$ for each point sampling. The collected water sample from this procedure were kept in bottles and sent to the laboratory for analysis.

Sampling were done at 5 (five) points at Tambak Lorok Coastal area (Figure 1.). Point 1 was located close to the mainland. Point 2 was selected due to its vicinity to the main water canal that flows from the center of the city of Semarang out to as estuary (East Banjir Canal estuary) at Tambak Lorok coast. Point 3 was located $500 \mathrm{~m}$ from point 1 to determine possible variances in microplastic concentrations from point 1 . Point 4 was selected to determine if there were significant differences in the microplactics as this point is closest to both the main electrical power plant (Indonesia Power) for Semarang City and a very large garment factory. Point 5 is selected furthest away from the coast and had the least number of community and commercial activity in Tambak Lorok coastal area. These five collection points were chosen as the to the representative of Tambak Lorok coastal area.

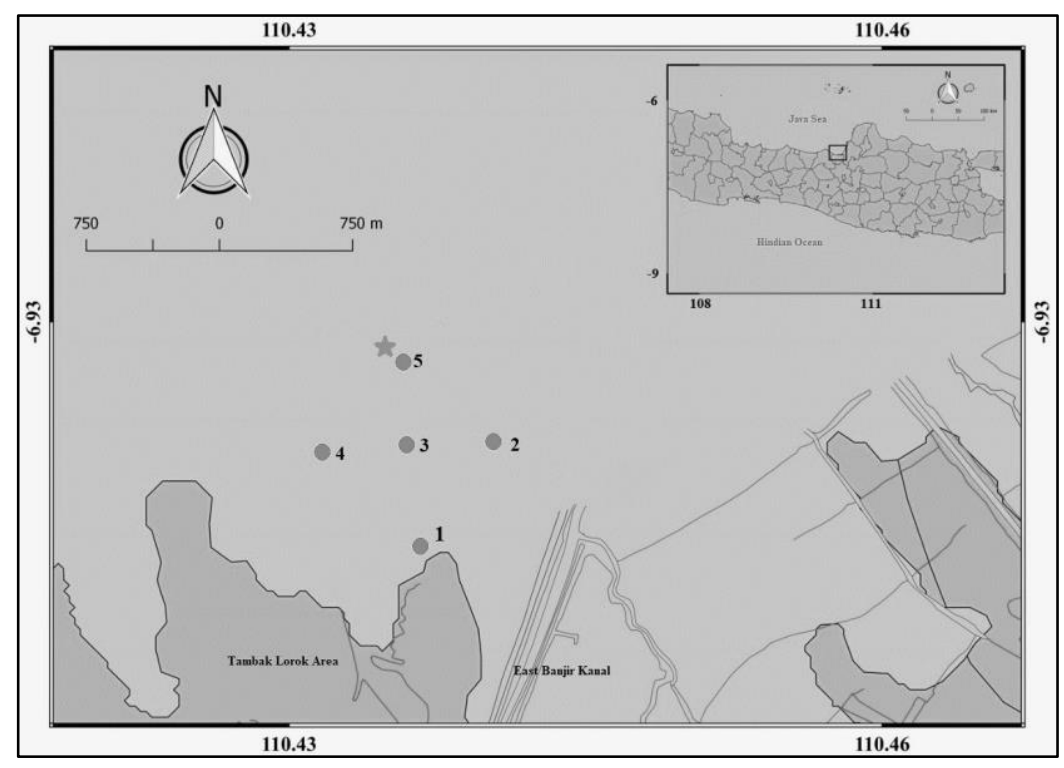

Figure 1. The sampling site in Tambak Lorok Coastal Area, Semarang City, Indonesia. 
P. placenta samples were collected using a "Garok" net fishing gear operated by local fishermen in the Tambak Lorok Coastal area. This oyster can be found at the waterbed of this coastal area which is about $5 \mathrm{~m}$ deep from the water surface. The samples were put in the cool box, transferred to the laboratory, and kept in $-20^{\circ} \mathrm{C}$ refrigerator for microplastic analysis. The star shape point in Figure 1 was the location of $P$. placenta sampling.

Before separation and analysis, distilled water, $\mathrm{NaCl}$, and $\mathrm{H}_{2} \mathrm{O}_{2}$ solution were treated in order to reduce contamination of the microplastics from other sources, and all the instruments were rinsed three times with filtered distilled water (Li et al., 2015). For each microplastic separation, water samples were filtered using sterile Whatman ${ }^{\circledR}$ cellulose nitrate filter papers (diameter $47 \mathrm{~mm}$; pore size $0.45 \mu \mathrm{m}$ ) (Cordova and Hernawan 2018). Gast Vacuum Pump was used to accelerate the filtration process. After filtering, Whatman paper was then dried in the oven at $105^{\circ} \mathrm{C}$ for 30 mins (Alam et al. 2019).

The procedure by Li et al. (2016; 2019) was used to separate microplastics from $P$. placenta samples. The shell length/weight of each sample was recorded. The $5 \mathrm{~g}$ of one individual soft tissue were placed in a $1000 \mathrm{~mL}$ glass bottle covered by aluminum foil and counted as one replicate. Six replicates were used for this study. Next, $200 \mathrm{~mL}$ of $30 \% \mathrm{H}_{2} \mathrm{O}_{2}$ was used to digest the soft tissues in the bottles. The magnetic stirrer bar was used at $65^{\circ} \mathrm{C}$ at $80 \mathrm{rpm}$ for $24 \mathrm{~h}$ to accelerate the digestion process. The bottles were then placed at room temperature for 24-48 $\mathrm{h}$ (depending on the digestion process) until the solution was clear and no more soft tissues were visible. Density separation by 1.2 g. $\mathrm{mL}^{-1} \mathrm{NaCl} 800 \mathrm{~mL}$ was used to separate the microplastics from each bottle that contain the dissolved liquid of the soft tissue overnight. The overlying water was gently discarded and filtered with Whatman ${ }^{\circledR}$ cellulose nitrate filter papers (diameter $47 \mathrm{~mm}$; pore size $0.45 \mu \mathrm{m}$ ) using a Gast Vacuum Pump (Model: DOA P504 - BN, USA) on 20 BAR pressure value. The filter was then placed into clean covered Petri dishes for analysis.

The microscope and FTIR spectroscopy were used to characterize the microplastics that have been separated from the water and $P$. placenta samples ( $\mathrm{Li}$ et al., 2016; 2017; 2018). The microscope was used to determine the shape, color, and size of the microplastics. Olympus SZX10 Research High-Class Stereomicroscope (Olympus Corporation, Japan) and an Olympus UC30 digital camera were used to observe the filter. ImageJ software was also used for analysis. Polymer type of microplastics was identified using Perkin Elmer Frontier FT-IR with $\mathrm{KBr}$ Pellet preparation. Microplastic particles were transformed into powder and homogenized with the $\mathrm{KBr}$ (potassium bromide) pellet. The homogenized sample was pressed in a hydraulic instrument for 5 mins. The pressed samples were then ready to be analyzed on the FTIR. The polymer types were determined within the wavelength range of $4000-400 \mathrm{~cm}^{-1}$. Microsoft Excel 2013 was used to process and present data findings.

\section{Results and Discussion}

According to Khoironi et al. (2020), mismanagement of the plastic waste by the city and its residents directly contributes to high level of microplastics present in the Tambak Lorok coastal area. In this study, microplastics were found in all the water and $P$. placenta samples. The abundance of microplastic in Tambak Lorok Water is shown in Table 1. The abundance of microplastics in $P$. placenta were 6 particles. Although microplastics were found in all sampling points of Tambak Lorok waters and $P$. placenta samples, the data indicates that there are relatively low in numbers. However presence of microplastics in both seawater and biota is very closely related to local community activities, which contribute to the dumping of plastic waste in the sea (Khoironi et al., 2020).

The abundance of microplastics in this study was classified by shape, color, size, and type of polymer that it is made. The number of microplastics found in this study is still relatively low when compared to previous studies related to the abundance of microplastics. This could be due to differences in methods used when sampling microplastics in the water (Besley et al., 2017). Other research studies states that contributions from streams is one of major contirbuting factor of microplastic pollution (Alam et al., 2019; Zheng et al., 2019), and some estuaries have been identified as microplastic hotspots (Wright et al., 2013).

Table 1. Microplastic abundance in the water sample from Tambak Lorok Coastal

\begin{tabular}{cc}
\hline Point & $\begin{array}{c}\text { The abundance of Microplastics } \\
\left(\text { Particle per } 5 \mathrm{~m}^{3}\right)\end{array}$ \\
\hline 1 & 17 \\
2 & 16 \\
3 & 15 \\
4 & 9 \\
5 & 6 \\
Total & 63 \\
Average & 12.6 \\
\hline
\end{tabular}


Collection point 1 was the highest number of microplastics. See Table 1. This was due to the location of this collection point in which it is nearest to the mainland where there is a high level activity by the residences of the local community. The presence of microplastics is often associated with the amount of population and resident activities (Desforges et al., 2014).

Fragment, fiber, and granule were detected in the seawater sample which is shown in Figure 2. Fragment was the most dominant shape of the microplastics in the water samples. The source of these shapes was most likely from the plastics used daily by the nearby communities and mismanaged plastic waste. This study had similar results with a survey that was conducted by Syakti et al. (2018) in Bintan Water, Riau Islands, in which is the most dominant shape of the microplastic found in that area was Fragment. However, the microplastics concentrations of the Tambak Lorok waters found in this study were lower than those of the Bintan waters (Syakti et al., 2018).

The most dominant shape found in P. placenta was fiber shaped. See Table 3. Other studies also found that fiber shaped was the most dominant form found in bivalve/mussels ( $\mathrm{Li}$ et al., 2019). One possible explanation is that the fibers in mussels are due to the result from long-term accumulation in the marine environment as compared to the other shapes (Li et al., 2019). The delay in the egestion of synthetic fibers was also evident since only fibers were detected in mussels after gut clearance period (De Witte et al., 2014). The presence of Fiber forms could be the result from clothes washing of residents directly and indirectly on the coastal waters and the existence of textile industries in the vicinity of the sampling points in this study. The water samples had more of a fragment shape where the $P$. placenta had predominately the fiber shaped microplastic.

Table 2. Total Concentration of Microplastics in water sample based on the shape

\begin{tabular}{ccc}
\hline Shape & $\mathrm{n}$ particle & $\begin{array}{c}\text { Total Concentration } \\
\text { Average } \pm \text { SDEV }\end{array}$ \\
\hline Fragment & 42 & $8.4 \pm 4.67$ \\
Fiber & 20 & $4.0 \pm 1.41$ \\
Granule & 1 & $0.2 \pm 0.45$ \\
\hline
\end{tabular}

Table 3. Shape of Microplastics Total Number found in Placuna placenta

\begin{tabular}{cccc}
$\begin{array}{c}\text { Number of } \\
\text { Organisms }\end{array}$ & $\begin{array}{c}\text { Total } \\
\text { Weight } \\
(\mathrm{g})\end{array}$ & $\begin{array}{c}\text { Shape } \\
\text { Category }\end{array}$ & $\begin{array}{c}\text { Total } \\
\text { Number of } \\
\text { Particle }\end{array}$ \\
\hline \multirow{2}{*}{6} & 30 & Fiber & 5 \\
& & Fragment & 1 \\
\hline
\end{tabular}

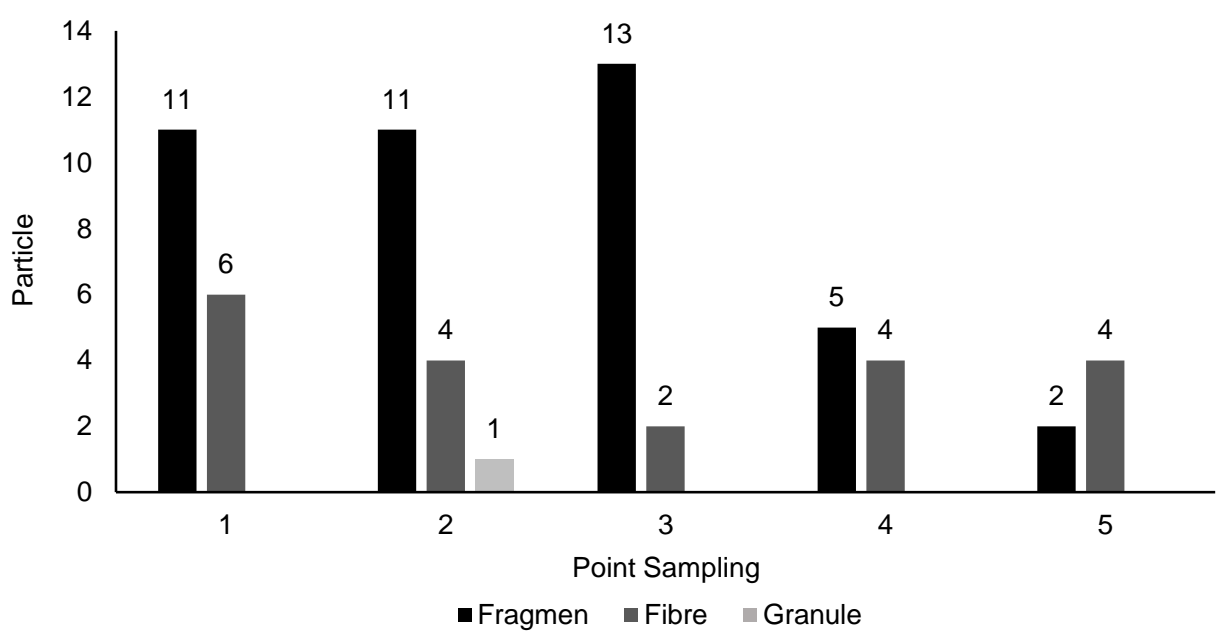

Figure 2. The shape of Microplastics from Waters

Table 4. Size of Microplastics in Tambak Lorok water

\begin{tabular}{ccc}
\hline Size & n particle & $\begin{array}{c}\text { Total Concentration } \\
\text { Average } \pm \text { SDEV }\end{array}$ \\
\hline$<50 \mu \mathrm{m}$ & 35 & $7.0 \pm 4.41$ \\
$50-100 \mu \mathrm{m}$ & 8 & $1.6 \pm 0.89$ \\
$100-500 \mu \mathrm{m}$ & 2 & $0.4 \pm 0.89$ \\
$500-1000 \mu \mathrm{m}$ & 5 & $1.0 \pm 0.70$ \\
$>1000 \mu \mathrm{m}$ & 13 & $2.6 \pm 1.14$ \\
\hline
\end{tabular}


ILMU KELAUTAN: Indonesian Journal of Marine Sciences March 2022 Vol 27(1):53-60

Table 5. Size of Microplastics in Placuna placenta

\begin{tabular}{cccccc}
\hline $\begin{array}{c}\text { Number of } \\
\text { Organisms }\end{array}$ & Total Weight & Size Category & $\begin{array}{c}\text { Total Number } \\
\text { of Particle }\end{array}$ & Particle.Individual-1 & Particle.gr-1 $^{-1}$ \\
\hline 6 & 30 & $<300 \mu \mathrm{m}$ & 1 & 0.167 & 0.033 \\
& & $300-1000 \mu \mathrm{m}$ & 4 & 0.667 & 0.133 \\
& $>1000 \mu \mathrm{m}$ & 1 & 0.167 & 0.033 \\
\hline
\end{tabular}

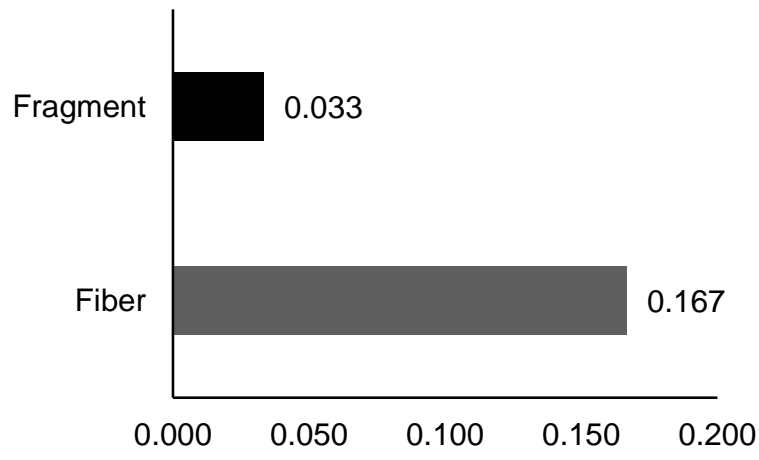

Microplastics concentration per wet weight

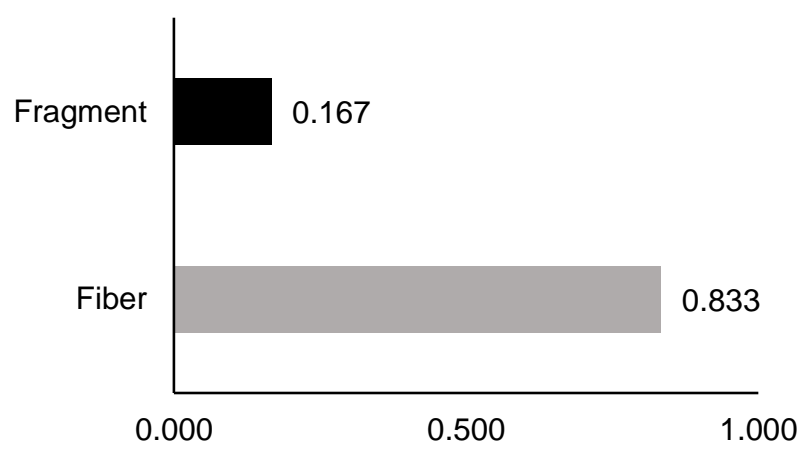

Microplastics concentration per individual

Figure 3. The shape of Microplastics in Windowpane Oyster Placuna placenta

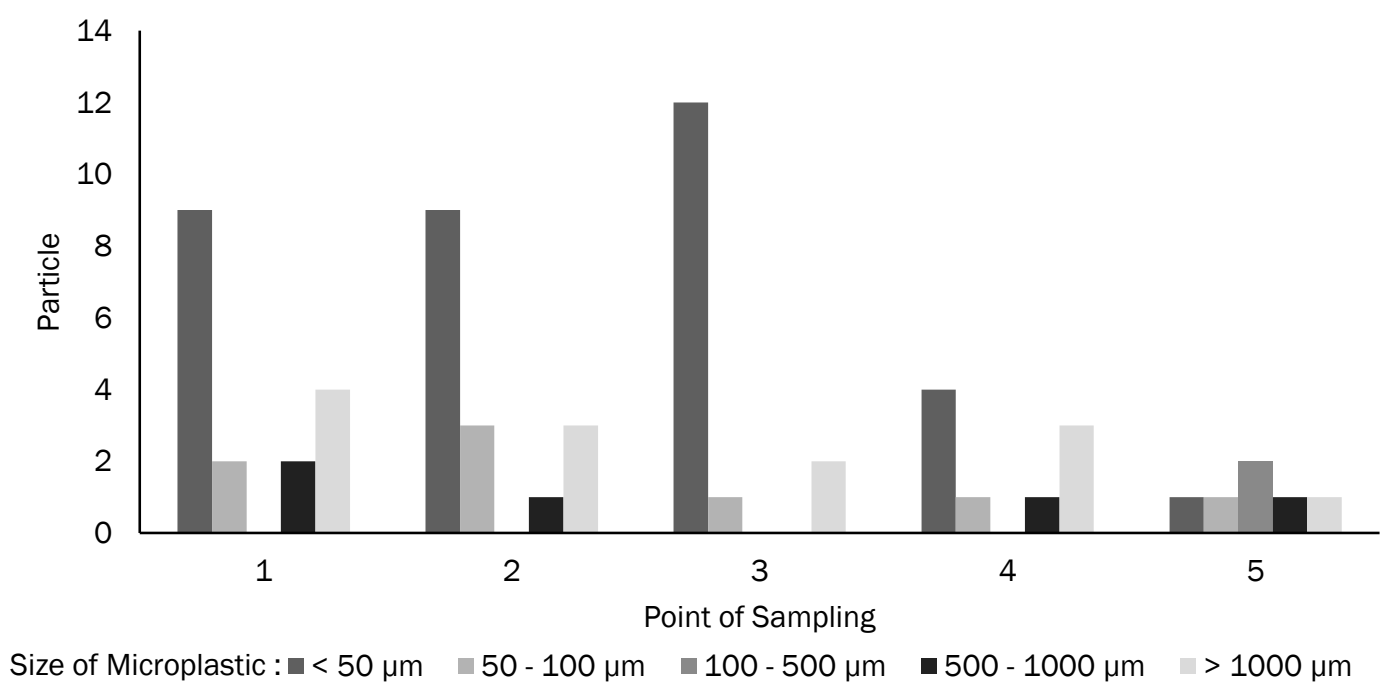

Figure 4. Size abundance of microplastics in Tambak Lorok Waters

Microplastic abundance in both samples was closely related to human activity, and the result from areas with intensive human activities contain significantly higher numbers (Li et al., 2016).

The microplastic size is an important characteristic since it will determine the possibility of being ingested by various marine organisms (Cole et al., 2013). It is also possible that microplastic could be digested in humans through the food chain where the microplastics are ingested by the marine organism. Small size $(0.05-0.25 \mathrm{~mm})$ microplastics can be ingested by the mussels (Kolandhasamy et al.,
2018). In this study, microplastic size was divided into five classes for the seawater sample which is presented in Table 4, and three classes for $P$. placenta.This study found that class $<50 \mu \mathrm{m}$ of microplastics was mostly found in the seawater sample. This can be due to small microplastics with low densities that will float in water. Particle size showed a significant effect on the modelled fate and retention of microplastic (Besseling et al., 2017).

In this study, microplastics obtained from $P$. placenta sample had a size range of $<300 \mu \mathrm{m}, 300$ $1000 \mu \mathrm{m}$, and >1000 $\mu \mathrm{m}$. See Table 5. Compared to 
ILMU KELAUTAN: Indonesian Journal of Marine Sciences March 2022 Vol 27(1):53-60

Table 6. The Color of Microplastic in Placuna placenta

\begin{tabular}{cccccc}
\hline $\begin{array}{c}\text { Number of } \\
\text { Organisms }\end{array}$ & Total Weight & Color Category & $\begin{array}{c}\text { Total Number } \\
\text { of Particle }\end{array}$ & Particle.Individual-1 & Particle.gr-1 $^{-1}$ \\
\hline 6 & 30 & Blue & 5 & 0.833 & 0.167 \\
& & Tosca & 1 & 0.167 & 0.033 \\
\hline
\end{tabular}

Table 7. Polymer Types found in both samples

\begin{tabular}{ccc}
\hline Sample & Polymer Type & $(\mathrm{n})$ \\
\hline & PS & 2 \\
Tambak Lorok Waters & Nylon & 5 \\
& PP & 2 \\
P. placenta & Nylon & 1 \\
\hline
\end{tabular}

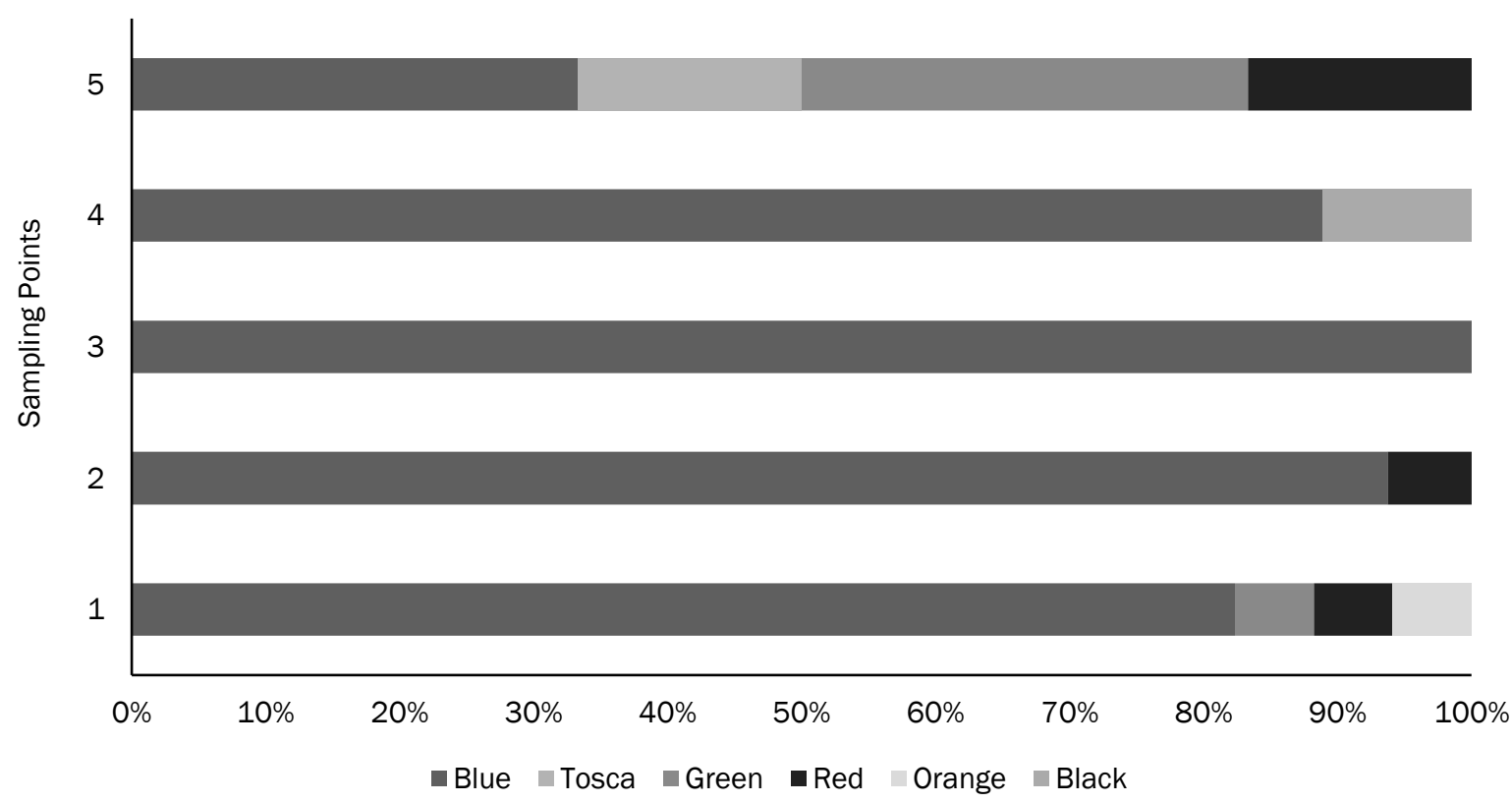

Figure 5. The color distribution of microplastics in Tambak Lorok Water

the study conducted by Kolandhasamy et al. (2018), the microplastic size obtained from Mytilus edulis is 0.05-0.25 mm (50-250 $\mu \mathrm{m})(>70 \%)$. However, these authors also suggested that the bigger size of microplastics can be found in mussels because of its adherence to specific organs of bivalve, rather than ingestion.

The color of microplastics can provide insight as to the level of contamination and its potential to be consumed by aquatic biota (Syakti et al., 2018). Based on the results of this study, Blue microplastic was the most dominant microplastic found in all the 5 sampling points (86\%), followed by red and green $(5 \%)$, black (2\%), orange and tosca (1\%) (Figure 5.) We assumed that the color of these microplastics was derived from its origin as well as colors that have been degraded. The color of microplastics may have implications for possible ingestion by pelagic organisms such as pelagic fish. Light-colored plastics may appear and account for a majority of microplastics in marine environments (Syakti et al. 2018). The color of microplastics found in the $P$. Placenta samples, which is presented in Table 6, were most possibly from the living conditions in their immediate ecosystem.

Among the microplastic found in both samples, selective microplastic samples were further analyzed to determine the type of polymer using FTIR. The results of the polymer spectrum of the samples were compared to the plastic-used polymer spectrum FTIR analysis in Jung et al. (2018). FTIR analysis showed three types of polymers (Table 7 .), nylon $(1389,1535$, 
1640 , and $2856 \mathrm{~cm}^{-1}$ ), polystyrene (PS; 2852,1034, 1638 , and535 $\mathrm{cm}^{-1}$ ), polypropylene (PP; 2925, 1454, 1377, 1161 and $841 \mathrm{~cm}^{-1}$ ). The most common polymer found from both samples were polypropylene (PP) and nylon. Similar results were also obtained by Khoironi et al. (2020). Polypropylene (PP) found in this study is suspected to be mainly from food and beverage packaging. PS type was suspected to be derived from fragmentation of food containers and or styrofoam cool-boxes used by fishermen in Tambak Lorok as storage containers for marine catch.

\section{Conclusion}

This study concludes that Tambak Lorok Coastal Waters and the oyster $P$. placenta have been contaminated by microplastic debris. Fragments and fibers microplastics were the most common shapes found in both samples. Polypropylene and nylon were most found polymer types in both samples. Even though the numbers of microplastics in this study were low compared to other studies, the presence of plastic waste contributes to the unhealthy contamination of the ocean ecosystem, degrading the marine environment and marine wildlife.

\section{Acknowledgment}

The author would like to thank all the laboratory staff from Tropical Marine Biotechnology Laboratory and Biology Laboratory of Marine Science Department Diponegoro University in their assistance in indentifying the microplastics. The author would also like to thank Mr. Rodhotul Muttaqin for his aid in analyzing the polymer types in this study using FTIR Spectroscopy.

\section{References}

Alam, F.C., Sembiring, E., Muntalif, B.S. \& Suendo, V. 2019. Microplastic distribution in surface water and sediment river around slum and industrial area (case study: Ciwalengke River, Majalaya district, Indonesia). Chemosphere, 224:63745. https://doi.org/10.1016/j.chemosphere.20 19.02.188

Ambariyanto, A. 2017. Conserving endangered marine organisms: causes, trends and challenges. In IOP Conference Series: Earth and Environmental Science, 55(1): 012002. https://doi.org/10.1088/1755-1315/55/1/01 2002

Besley, A., Martina, G.V., Behrens, P. \& Bosker, T. 2017. A standardized method for sampling and extraction methods for quantifying microplastics in beach sand. Mar. Poll. Bull., 114(1): 77-83. https://doi.org/10.1016/j.marpolbul.2016.08. 055

Besseling, E., Quik, J.T.K., Sun, M. \& Koelmans, A.A. 2017. Fate of nano- and microplastic in freshwater systems: A modelling study. Environmental Poll., 220: 540-48. https://doi.org/10.1016/j.envpol.2016.10.001

Browne, M.A. 2015. Sources and pathways of microplastics to habitats. 229-44 in Marine anthropogenic litter. Springer, Cham. https://doi.org/10.1007/978-3-319-16510-3_9

Cole, M., Lindeque, P., Fileman, E., Halsband, C., Goodhead, R., Moger, J. \& Galloway T.S. 2013. Microplastic ingestion by zooplankton. Environ. Sci. Technol., 47(12): 6646-6655. https://doi. org/10.1021/es400663f

Cordova, M.R. \& Hernawan, U.E. 2018. Microplastics in Sumba waters, East Nusa Tenggara. In IOP Conference Series: Earth and Environmental Science. 162. https://doi.org/10.1088/17551315/162/1/012023

Desforges, J-P. W., Galbraith, M., Dangerfield, N. \& Ross, P.S. 2014. Widespread distribution of microplastics in subsurface seawater in the NE Pacific Ocean. Mar. Poll. Bull., 79(1-2): 94-99. https://doi.org/10.1016/j.marpolbul.2013.12. 035

Plastics Europe. 2015. Plastics-the facts 2015 an analysis of European plastics production, demand and waste data. Plastics Europe, Association of Plastic Manufacturers Brussels.

Farrell, P. \& Nelson, K. 2013. Trophic level transfer of microplastic: Mytilus edulis (L.) to Carcinus maenas (L.). Environ. Poll., 177: 1-3. https://doi.org/10.1016/j.envpol.2013.01.046

Isobe, A. 2016. Percentage of microbeads in pelagic microplastics within Japanese coastal waters. Mar. Poll. Bull., 110(1): 432-37. https://doi. org/10.1016/j.marpolbul.2016.06.030

Jambeck, J.R., Geyer, R., Wilcox, C., Siegler, T.R., Perryman, M., Andrady, A., Narayan, R. \& Law, K.L. 2015. Plastic waste inputs from land into the ocean. Science, 347(6223): 768-71. https://doi.org/10.1126/science.1260352

Jung, M.R., Horgen, F.D., Orski, S.V., Rodriguez, V., Beers, K.L., Balazs, G.H., Jones, T.T., Work, T.M., Brignac, K.C. \& Royer S.J. 2018. Validation of ATR FT-IR to identify polymers of plastic marine debris, including those ingested by marine 
organisms. Mar. Poll. Bull., 127: 704-16. https://doi.org/10.1016/j.marpolbul.2017.12. 061

Khoironi, A., Hadiyanto, H., Anggoro, S. \& Sudarno, S. 2020. Evaluation of polypropylene plastic degradation and microplastic identification in sediments at Tambak Lorok coastal area, Semarang, Indonesia. Mar. Poll. Bull., 151: 110868. https://doi.org/10.1016/j.marpolbul. 2019.110868

Kolandhasamy, P., Su, L., Li, J., Qu, X., Jabeen, K. \& Shi, H. 2018. Science of the Total Environment Adherence of microplastics to soft tissue of mussels: A novel way to uptake microplastics beyond ingestion. Sci. Total Environ., 610-611: 635-640. https://doi.org/10.1016/j.scitotenv. 2017.08.053

Kusnoputranto, H., Moersidik, S.S., Wisnubroto, D.S. \& Makmur M. 2014. Accumulation and Depuration of PSP Toxin (Paralytic Shellfish Poisoning) by Green Mussels. ILMU KELAUTAN: Indonesian Journal of Marine Sciences, 19(1): 27-34. https://doi.org/10.14710/ik.ijms.19.1. $27-34$

Li, J., Lusher, A.L., Rotchell, J.M., Deudero, S., Turra, A., Bråte, I.L.N., Sun, C., Hossain, M.S., Li, Q. \& Kolandhasamy P. 2019. Using mussel as a global bioindicator of coastal microplastic pollution. Environ.l Poll., 244: 522-33. https://doi.org/10.1016/j.envpol.2018.10.032

Li, J., Qu, X., Su, L., Zhang, W., Yang, D., Kolandhasamy, P., Li, D. \& Shi, H. 2016. Microplastics in mussels along the coastal waters of China. Environmental Poll., 214: 177-84. https://doi.org/10.1016/j.envpol.2016.04.012

Li, J., Yang, D., Li, L., Jabeen, K. \& Shi, H. 2015. Microplastics in commercial bivalves from China. Environ. Poll., 207: 190-95. https://doi.org/10.1016/j.envpol.2015.09.018

Löhr, A., Savelli, H., Beunen, R., Kalz, M., Ragas, A. \& Belleghem, F. V. 2017. Solutions for global marine litter pollution. Curr. Opin. Environ. Sustain, 28: 90-99. https://doi.org/10.1016/j. cosust.2017.08.009

Lusher, A., Hollman, P. \& Mendoza-Hill J. 2017. Microplastics in fisheries and aquaculture: status of knowledge on their occurrence and implications for aquatic organisms and food safety. FAO. Fisheries and Aquaculture Technical Paper 615, 126 pp.

Nerland, I.L., Halsband, C., Allan, I. \& Thomas K.V. 2014. Microplastics in marine environments: Occurrence, distribution and effects. Norwegian Institute for Water Research. Report SNO. 6754 2014, $71 \mathrm{pp}$.

Syakti, A.D., Bouhroum, R., Hidayati, N.V., Koenawan, C.J., Boulkamh, A., Sulistyo, I., Lebarillier, S., Akhlus, Sy., Doumenq, P. \& Wong-Wah-Chung, P. 2017. Beach macro-litter monitoring and floating microplastic in a coastal area of Indonesia. Mar. Poll. Bull., 122(1-2):217-25. https://doi.org/10.1016/j.marpolbul.2017.06. 046

Syakti, A.D., Hidayati, N.V., Jaya, Y.V., Siregar, S.H., Yude, R., Suhendy, Asia, L., Wong-Wah-Chung, P. \& Doumenq, P. 2018. Simultaneous grading of microplastic size sampling in the Small Islands of Bintan water, Indonesia. Mar. Poll. Bull., 137: 593-600. https://doi.org/10.1016/j.marpolbul. 2018.11.005

Tubagus, W., Sunarto, S., Ismail, M.R., \& Yuliadi, L.P. S. 2020. Identification of Microplastic Composition on Clams (Gafrarium tumidum) and Sediments in Seribu Island, Pari Island Area, DKI Jakarta. IImu Kelautan: Indonesian Journal of Marine Sciences, 25(3): 115-120. https://doi.org/ 10.14710/ik.ijms.25.3.115-120

De Witte B., Devriese L., Bekaert K., Hoffman S., Vandermeersch G., Cooreman K., Robbens J. 2014. Quality assessment of the blue mussel (Mytilus edulis): Comparison between commercial and wild types. Mar. Poll. Bull., 5(1): 146-155. https://doi.org/10.1016/j.marpolbul. 2014.06.006

Wright, S.L., Thompson, R.C. \& Galloway, T.S. 2013. The physical impacts of microplastics on marine organisms: a review. Environ. Poll., 178: 483-492. https://doi.org/10.1016/j.envpol.2013.02.031

Zheng, Y., Li, J., Cao, W., Liu, X., Jiang, F., Ding, J., Yin, X. \& Sun, C. 2019. Distribution characteristics of microplastics in the seawater and sediment: A case study in Jiaozhou Bay, China. Sci. Total Environ., 674: 27-35.https://doi.org/10.1016/ j.scitotenv. 2019.04.008 